\title{
Effect of maleic hydrazide on respiratory parameters of stored onion bulbs (Allium cepa L.)
}

\author{
Noureddine Benkeblia
}

Department of Food Science, Rakuno Gakuen University, Ebetsu, Hokkaido 069 8501, Japan. E-mail: ben-nour@rakuno.ac.jp

The respiration rate (RR) $\left(\mathrm{CO}_{2}\right.$ production), activation energy $\left(E_{a}\right)$ and $Q_{10}$ of maleic hydrazide-treated onion bulbs (Allium cepa, cv. Rouge Amposta) at $20.10^{-6} \mathrm{~mol} \cdot \mathrm{L}^{-1}\left(\mathrm{MH}_{1}\right)$ and $45.10^{-6} \mathrm{~mol} \cdot \mathrm{L}^{-1}\left(\mathrm{MH}_{2}\right)$ were measured at 4,10 and $20^{\circ} \mathrm{C}$. Immediately after treatment, the $Q_{10}$ of $\mathrm{MH}$-treated and control bulbs were not significantly different. After 8 weeks of storage, $Q_{10}$ of control and both $\mathrm{MH}$-treated bulbs increased and ranged from 2.34 and 2.89. Respiration rate of onions increased during storage, and after 24 weeks, $\mathrm{RR}$ values of control, $\mathrm{MH}_{1}$ and $\mathrm{MH}_{2}$ were $0.43,0.32$ and $0.26 \mathrm{mmol} \mathrm{CO}{ }_{2} \cdot \mathrm{kg}^{-1} \cdot \mathrm{h}^{-1}$ at $20^{\circ} \mathrm{C}$ respectively; and $0.26,0.20$ and $0.17 \mathrm{mmol} \mathrm{CO} \mathrm{CO}_{2} \cdot \mathrm{kg}^{-1} \cdot \mathrm{h}^{-1}$ at $10^{\circ} \mathrm{C}$ respectively. At $4^{\circ} \mathrm{C}$, no significant difference was observed between control and $\mathrm{MH}$-treated bulbs. After 24 weeks, sprouting of the control and $\mathrm{MH}_{1}$ and $\mathrm{MH}_{2}$-treated bulbs was $75 \%, 38 \%$ and $33 \%$ at $20^{\circ} \mathrm{C}$ respectively, and $50 \%, 22 \%$ and $17 \%$ at $10^{\circ} \mathrm{C}$ respectively. At $4^{\circ} \mathrm{C}$, the sprouting level of control bulbs did not exceed $7 \%$ and was $5 \%$ for $\mathrm{MH}$-treated bulbs. No difference was observed in rotting of control and $\mathrm{MH}$-treated bulbs, and the low rotting observed at $4^{\circ} \mathrm{C}$ could be attributed to low temperature rather than maleic hydrazide treatment.

Key words: activation energy, $\mathrm{MH}$, onion, $Q_{10}$, respiration rate, sprouting, storage.

Efeito da hidrazida maléica sobre parâmetros respiratórios de bulbos armazenados de cebola (Allium cepa L.): A taxa respiratória (produção de $\mathrm{CO}_{2}$ ), energia de ativação (Ea) e $Q 10$ de bulbos de cebola (Allium cepa, cv. Rouge Amposta) tratados com hidrazida maléica nas concentrações de $20.10^{-6}$ mol.L-1 $\left(\mathrm{MH}_{1}\right)$ e $45.10^{-6}$ mol.L-1 $\left(\mathrm{MH}_{2}\right)$ foram medidas a 4,10 e $20^{\circ} \mathrm{C}$. Imediatamente após os tratamentos, os valores de $Q 10$ de bulbos do tratados e controles não foram diferentes. Após 8 semanas de armazenamento, os valores de $Q 10$ dos controles e dos bulbos tratados aumentou, ficando entre 2,34 e 2,89. A taxa respiratória dos bulbos aumentou durante a armazenagem e após 24 semanas, os valores do controle de $\mathrm{MH} 1$ e MH2 foram 0,43, 0,32 and $0,26 \mathrm{mmol} \mathrm{CO} \cdot \mathrm{kg}^{-1} \cdot \mathrm{h}^{-1}$ a $20^{\circ} \mathrm{C}$ respectivamente, e $0,26,0,20$ e $0,17 \mathrm{mmol} \mathrm{CO}_{2} \cdot \mathrm{kg}^{-1} \cdot \mathrm{h}^{-1}$ a $10^{\circ} \mathrm{C}$ respectivamente. A $4^{\circ} \mathrm{C}$, não se observou diferença entre controle e bulbos tratados com hidrazida maléica. Após 24 semanas, as brotações do controle, $\mathrm{MH}_{1} \mathrm{e}$ $\mathrm{MH}_{2}$ foram $75 \%, 38 \%$ e $33 \%$ a $20^{\circ} \mathrm{C}$ respectivamente, e $50 \%, 22 \%$ e $17 \%$ a $10^{\circ} \mathrm{C}$ respectivamente. A $4^{\circ} \mathrm{C}$, o nível de brotação nos bulbos-controle não excedeu $7 \%$, sendo de $5 \%$ para os tratados. Nenhuma diferença foi observada quanto ao apodrecimento de ambos os bulbos, e o pouco apodrecimento verificado a $4^{\circ} \mathrm{C}$ poderia ser atribuído à baixa temperatura do que a um efeito do tratamento com hidrazida maléica.

Palavras-chave: armazenamento, brotação, cebola, energia de ativação, $Q_{10}$, taxa respiratória.

\section{INTRODUCTION}

Immediately after harvest, onion bulbs are in a natural state of dormancy that is controlled by endogenous hormones and varies with genetic make-up of the particular cultivar. However, environmental factors particularly temperature, affect dormancy and may prolong or shorten the dormancy period. The commercial storage period for onion bulbs is characterized by the initiation of root growth and sprout elongation (Abdallah and Mann, 1963).
During their storage, onion bulbs are exposed to environmental conditions including temperatures which can affect their physiological and biochemical parameters. Changes observed in quality attributes of stored onions are the result of high catabolism of substrates, primarily carbohydrates but may also include organic acids. Recent development in storage technologies, e.g. modified/controlled atmosphere packaging (MA/CA) and the use of rare gases (nitrous oxide, argon), require the determination of 
physiological parameters to predict gas exchanges of whole onion bulbs as well as the behavior of this vegetable during storage. This is especially true when sprouting control techniques such as chemical inhibitors were previously applied during growth or after harvesting using ionization, for example (Benkeblia, 2003). Nevertheless, values for physiological parameters of onions, as for most Allium crops, including activation energy, $Q_{10}$ and their variations with chemical treatment stresses and sprouting are not readily available in the current literature.

Maleic hydrazide (1,2-dihydro-3,6-pyridazinedione) is used as a systemic plant growth regulator or inhibitor and herbicide, and has enjoyed extensive use as a commercial onion sprout inhibitor since its introduction in the 1940s'. A dilution of 9.10${ }^{9}$ mol.L-1 inhibits the growth of a vast number of plants including Alliums. The effect of MH is to inhibit mitosis in the meristematic region, and plant metabolic studies have shown that, besides its many physiological side activities, $\mathrm{MH}$ acts as an antagonist of pyrimidine bases (Appleton et al., 1981). These authors noted that $\mathrm{MH}$ is incorporated into RNA of cells where it substituted for cytosine rather than for uracil, its structural isomer. Incorporation was found to take place in the undifferentiated RNA fraction, as well as in tRNA. This fact may explain the mode of action of $\mathrm{MH}$ with regard to its ability to interfere with protein biosynthesis and cell growth.

With regard to plant metabolism, it has been stated that MH becomes fixed within the plant and is not metabolized, however the conversion of $\mathrm{MH}$ to its $\beta$-D- glucoside as the predominant soluble metabolite, with a yield of between 2 and 15\%, was reported by Komossa and Sandermann (1995). Benkeblia et al. (2002) reported that the respiration rate of $\mathrm{MH}$-treated onion bulbs stored at 10 and $20^{\circ} \mathrm{C}$ increased less compared to control bulbs, while the MH treatment did not affect carbohydrate status during storage. Unfortunately, no data are available on the effects of $\mathrm{MH}$ on physiological aspects related to sprout development of onion bulbs or other vegetable crops.

The objective of this study was to investigate the effects of maleic hydrazide and different temperatures on physiological parameters of stored onion bulbs.

\section{MATERIALS AND METHODS}

Onions: Onion bulbs, Allium cepa c.v. Rouge Amposta (organic product, free of any preharvest chemical treatments), freshly harvested and dried in the field for two weeks, were obtained from the local organic produce market. Bulbs were selected for uniformity and absence of defects, packed in commercial plastic (PVC) trays each of $12 \mathrm{~kg}$ and placed at $18^{\circ} \mathrm{C}$ during $24 \mathrm{~h}$ prior to $\mathrm{MH}$ treatment.

Chemical treatment: Onion bulbs were dipped into $20.10^{-6}$ mol.L $\mathrm{L}^{-1}\left(\mathrm{MH}_{1}\right)$ (recommended dose in agriculture), and 45.10-6 mol.L-1 $\left(\mathrm{MH}_{2}\right)$ (high stress dose) of maleic hydrazide solutions (Sigma, St Louis, MO, USA) for $15 \mathrm{~min}$. Then, they were dried in a ventilated oven at $35^{\circ} \mathrm{C}$ for $30 \mathrm{~min}$. Control bulbs were dipped into double-distilled water for $15 \mathrm{~min}$ and dried under the same conditions $\left(35^{\circ} \mathrm{C}\right.$ for $\left.30 \mathrm{~min}\right)$.

Storage conditions: Immediately after treatment, onions were stored at three combinations of temperature and relative humidity: $4^{\circ} \mathrm{C}$ and $85 \% \mathrm{RH}, 10^{\circ} \mathrm{C}$ and $80 \% \mathrm{RH}$ and ambient conditions of $20^{\circ} \mathrm{C}$ and $65 \% \mathrm{RH}$.

Respiration rate measurement: Respiration rate (RR) was determined by the glass jar technique (Benkeblia et al., 2000). At specific time intervals (after 1, 2, 3 and $5 \mathrm{~h}$ ), gas samples $(50 \mu \mathrm{L})$ were taken through a silicone septum and analyzed by a gas chromatograph (model M200, Microsensor Technology Inc., Fremont, CA, USA). The analyzer involved two manifolds: one fitted with a MS-5A, 4 m capillary column set at $80^{\circ} \mathrm{C}$ with argon as carrier gas at a flow rate of $20 \mathrm{ml}$. $\mathrm{min}^{-1}$, and the other fitted with a capillary Poraplot $4,6 \mathrm{~m}$ column set at $30^{\circ} \mathrm{C}$ with helium as carrier gas at a flow rate of $30 \mathrm{ml} \mathrm{min}{ }^{-1}$. Both manifolds were coupled to a thermal conductivity detector (TCD). Under such conditions, argon does not interfere with $\mathrm{O}_{2}$ peak. Rubber gaskets and silicone septa on the jars were changed after each experiment to prevent any air leakage. Respiration rate (RR) was calculated by linear regression from $\mathrm{CO}_{2}$ depletion curve and expressed as mmol. $\mathrm{kg}^{-1} \cdot \mathrm{h}^{-1}$. The mean value of respiration rate was determined from triplicate measurements $(3$ jars each containing $1 \mathrm{~kg}$ of onion).

Ethylene measurement: Ethylene was measured by a gas chromatograph (Delsi 200 model, IGC Instruments, Saulx les Chartreux, France) equipped with a flame ionizing detector at $110^{\circ} \mathrm{C}$ and fitted with an activated alumina column $(2 \mathrm{~m} \mathrm{x}$ $4 \mathrm{~mm}$, Altech, Deerfield, IL, USA) operated at $90^{\circ} \mathrm{C}$. The carrier gas was $\mathrm{N}_{2}$ with a flow rate of $30 \mathrm{~mL} \cdot \mathrm{min}^{-1}$ and the integrator was an Intersmat.ICR. 1B (IGC Instruments, Saulx les Chartreux, France).

Anaerobic respiration rate measurement (fermentative index): Anaerobic respiration rate (fermentative index or FI) was measured according to the method of Benkeblia et al. (2000). 
Anoxia was obtained under the following conditions: onion bulbs were placed in $2 \mathrm{~L}$ jars which were flushed with pure nitrogen $\left(\mathrm{N}_{2}\right)$. The final gas composition within the flushed jars was checked with a gas chromatograph and averaged from 99.5 to $99.7 \mathrm{kPa} \mathrm{N}_{2}$, and less than $0.2 \mathrm{kPa} \mathrm{O}_{2}$. At specific time intervals (after 3, 6, 12, 24 and 48 hours), gas samples $(50 \mu \mathrm{l})$ were taken from the vessels through a silicone septum and analyzed by a gas chromatograph (model M200, described above). The fermentative index (FI) was calculated by linear regression from $\mathrm{CO}_{2}$ depletion curve and expressed as mmol. $\mathrm{kg}^{-1} \cdot \mathrm{h}^{-1}$. The mean value of FI-CO 2 was determined from triplicate measurements ( 3 jars each containing $1 \mathrm{~kg}$ of onion).

Measurement of ethanol production: Ethanol production was measured by a gas chromatograph (DI.121FL model, IGC Instruments, Saulx les Chartreux, France) fitted with a Porapack T column (4 mm x 2 m, Alltech, Deerfield, IL, USA) set at $100^{\circ} \mathrm{C}$, and equipped with a flame-ionizing detector operating at $150^{\circ} \mathrm{C}$. The carrier gas was $\mathrm{N}_{2}$ with a flow rate of $30 \mathrm{ml} \cdot \mathrm{min}^{-1}$, and the integrator was an Intersmat (model ICR1B, IGC Instruments, Saulx les Chartreux, France). A sample of $100 \mu \mathrm{l}$ of a standard solution of ethanol $\left(10^{-4}\right.$ mol.L $\left.{ }^{-1}\right)$ was injected prior the analysis. The production of ethanol was compared with a standard solution considering the volume of the vessels and time. Ethanol production was calculated using the same equation of the fermentative index and expressed as pmol. $\mathrm{kg}^{-1} \cdot \mathrm{h}^{-1}$. The mean value of ethanol production was determined from triplicate measurements (3 jars each containing $1 \mathrm{~kg}$ ofonion).

$E_{a}$ and $Q_{10}$ calculation - Activation energy $\left(E_{a}\right)$ calculated as described by Labuza (1980), based on an Arrhenius equation:

$$
\ln \left(R R_{T}\right)=\frac{-E_{a}}{R} \cdot \frac{1}{(T+273)}+\ln \left(R R_{0}\right)
$$

$R R_{T}=$ respiration rate at temperature $T\left(\mathrm{mmol} \cdot \mathrm{kg}^{-1} \cdot \mathrm{h}^{-1}\right)$

$T=$ temperature $\left({ }^{\circ} \mathrm{C}\right)$

$E_{a}=$ Activation energy $\left(\mathrm{J} \mathrm{mol}^{-1}\right)$

$R=\operatorname{gas}$ constant $\left(8.3 \mathrm{~J} \cdot \mathrm{mol}^{-1} \cdot \mathrm{K}^{-1}\right)$

$Q_{10}$ was determined by plotting $\log (R R)$ against temperature $(T)$ according to the following equation:

$\log (R R)=a T+b$

$Q_{10}$ was calculated from the $a$ coefficient by the following equation:

$$
Q_{10}=10^{10 a}
$$

The respiration rate at $0^{\circ} \mathrm{C}\left(R R_{0}\right)$ was calculated by extrapolation from the $b$ coefficient by the following equation:

$$
R R_{0}=10^{b}
$$

Statistical analysis: Experiments were carried out during two successive years and all experiments were done in triplicate. Data were analyzed statistically by determination of least significant difference ( $L S D$ at $P<0.05)$ using Statistica 5.0 software (StatSoft, Maisons-Alfort, France).

\section{RESULTS AND DISCUSSION}

The effect of maleic hydrazide and temperature on respiratory parameters of fresh onions is reported in table 1. The respiratory quotient $\left(R Q=\right.$ ratio between $\mathrm{CO}_{2}$ production and $\mathrm{O}_{2}$ consunption whatever the pre-treatment and temperature) of onion bulb averaged from 0.84 to 0.90 at $20^{\circ} \mathrm{C}$ (data not shown). The ethylene production of onion is low compared with other vegetables, ranging from 40 to 48 nmol. $\mathrm{kg}^{-1} \cdot \mathrm{h}^{-1}$. According to Kubo et al. (1990), the sensitivity of onions to ethylene is very low and its production is less than $100 \mathrm{nmol} \cdot \mathrm{kg}^{-1} \cdot \mathrm{h}^{-1}$.

The $\mathrm{CO}_{2}$ fermentative index of onion was between 0.13 and $0.15 \mathrm{mmol} \mathrm{CO} \cdot \mathrm{kg}^{-1} \cdot \mathrm{h}^{-1}$ measured $6 \mathrm{~h}$ after closing the jars. The ethanolic fermentative index was very low compared with other crops, and averaged $0.77 \mathrm{pmol} . \mathrm{kg}^{-1} \cdot \mathrm{h}^{-1}$. Aerobic and anaerobic catabolism of onion bulb is rather moderate or low compared with other vegetables since the respiration rate is no more than $0.5 \mathrm{mmol} \cdot \mathrm{kg}^{-1} \cdot \mathrm{h}^{-1}$ (Weichmann, 1987). The same comment could be made on the fermentative index of onion which is low compared with other plants e.g. FI of asparagus is $1.08 \mathrm{mmol} \mathrm{CO} 2 \cdot \mathrm{kg}^{-1} \cdot \mathrm{h}^{-1}$ at $18^{\circ} \mathrm{C}$ (Peppelenbos et al., 1996).

The immediate and after two months effects of maleic hydrazide on respiratory parameters of bulbs are shown in tables 2 and 3. A non-significant difference was observed for $Q_{10}$ of $\mathrm{MH}_{1}$-treated and control bulbs, but for $\mathrm{MH}_{2}$-treated

Table 1. Respiration and fermentative rates of freshly harvested onion bulbs at $20^{\circ} \mathrm{C}$.

\begin{tabular}{cc}
\hline & Aerobic respiration \\
\hline $\mathrm{RR} \mathrm{O}_{2}$ & $0.19-0.21 \mathrm{mmol} \cdot \mathrm{kg}^{-1} \cdot \mathrm{h}^{-1}$ \\
$\mathrm{RR} \mathrm{CO}_{2}$ & $0.16-0.19 \mathrm{mmol} \cdot \mathrm{kg}^{-1} \cdot \mathrm{h}^{-1}$ \\
Ethylene & $40-48 \mathrm{nmol} . \mathrm{kg}^{-1} \cdot \mathrm{h}^{-1}$ \\
& Anaerobic respiration \\
FI CO & $0.13-0.15 \mathrm{mmol} \cdot \mathrm{kg}^{-1} \cdot \mathrm{h}^{-1}$ \\
FI ethanol & $0.76-0.78 \mathrm{pmol} \cdot \mathrm{kg}^{-1} \cdot \mathrm{h}^{-1}$ \\
\hline
\end{tabular}


onions $Q_{10 \mathrm{O} 2}$ and $\mathrm{Q}_{10 \mathrm{CO} 2}$ increased to 1.90 and 1.98 respectively. After two months of storage at $4^{\circ} \mathrm{C}$ and the onset of sprouting, $Q_{10}$ of control and both MH-treated bulbs increased and ranged from 2.34 and 2.89. This increase is partly due to the change in catabolism of the sprout tissues.

Table 2. Respiratory parameters of freshly harvested and MHtreated onion bulbs.

\begin{tabular}{lccc}
\hline & $E_{a}\left(\mathrm{~J} \cdot \mathrm{mol}^{-1}\right)$ & $Q_{10}$ & $\begin{array}{c}R R_{0} \\
\left(\mathrm{mmol} \mathrm{CO}_{2} \cdot \mathrm{kg}^{-1} \cdot \mathrm{h}^{-1}\right)\end{array}$ \\
\hline Control & 34999 & 1.67 & 0.077 \\
$\quad \mathrm{RR} \mathrm{O}_{2}$ & 41133 & 1.84 & 0.059 \\
$\mathrm{RR} \mathrm{CO}_{2}$ & & & \\
$\mathrm{MH}_{1}$ & 39867 & 1.70 & 0.079 \\
$\quad \mathrm{RR} \mathrm{O}_{2}$ & 31589 & 1.58 & 0.060 \\
$\mathrm{RR} \mathrm{CO}_{2}$ & & & \\
$\mathrm{MH}_{2}$ & 42331 & 1.90 & 0.074 \\
$\quad \mathrm{RR} \mathrm{O}_{2}$ & 47087 & 1.98 & 0.061 \\
$\mathrm{RR} \mathrm{CO}_{2}$ & & & \\
\hline
\end{tabular}

Table 3. Respiratory parameters of MH-treated onion bulbs and stored 2 months at $4^{\circ} \mathrm{C}$.

\begin{tabular}{lccc}
\hline & $E_{a}\left(\mathrm{~J} \cdot \mathrm{mol}^{-1}\right)$ & $Q_{10}$ & $\begin{array}{c}R R_{0} \\
\left(\mathrm{mmol} \mathrm{CO}_{2} \cdot \mathrm{kg}^{-1} \cdot \mathrm{h}^{-1}\right)\end{array}$ \\
\hline Control & & & \\
$\quad \mathrm{RR} \mathrm{O}_{2}$ & 59319 & 2.40 & 0.057 \\
$\quad \mathrm{RR} \mathrm{CO}_{2}$ & 71913 & 2.89 & 0.038 \\
$\mathrm{MH}_{1}$ & & & \\
$\quad \mathrm{RR} \mathrm{O}_{2}$ & 60102 & 2.47 & 0.038 \\
$\quad \mathrm{RR} \mathrm{CO}_{2}$ & 61313 & 2.47 & 0.032 \\
$\mathrm{MH}_{2}$ & & & \\
$\quad \mathrm{RR} \mathrm{O}_{2}$ & 55963 & 2.29 & 0.041 \\
$\mathrm{RR} \mathrm{CO}_{2}$ & 57447 & 2.34 & 0.038 \\
\hline
\end{tabular}

Van der Berg and Lentz (1972) noted that $Q_{10}$ values of onion bulbs varied during storage; the $Q_{10}$ value was 2.5 after two months and 3.5 after six months of storage with a subsequent increase in respiratiory heat production which is significantly affected by temperature during storage.

During storages, the respiration rate of control and $\mathrm{MH}-$ treated bulbs increased and showed a similar pattern, however increasing of control RR was more marked than that of $\mathrm{MH}-$ treated onions (figures 1A, B and C). After 12 weeks of storage, the $\mathrm{RR}_{\mathrm{CO} 2}$ values were $57 \%, 31 \%$ and $26 \%$ higher at $20^{\circ} \mathrm{C}$, and, $58 \%, 25 \%$ and $8 \%$ higher at $10^{\circ} \mathrm{C}$ for control, $\mathrm{MH}_{1}$ and $\mathrm{MH}_{2}$-treated onions respectively. After 24 weeks, these values were $128 \%, 68 \%$ and $37 \%$, at $20^{\circ} \mathrm{C}$, and, $116 \%$, $81 \%$ and $70 \%$ at $10^{\circ} \mathrm{C}$ respectively. The average rates of increase in respiration during the 24 weeks were determined by applying a linear regression. The increase in $\mathrm{RR}$ was 10,5 and $3 \mu \mathrm{mol} \mathrm{CO} \mathrm{CO}_{2} \cdot \mathrm{kg}^{-1} \cdot \mathrm{h}^{-1}$ per week at $20^{\circ} \mathrm{C}$, and 6,4 and 3 $\mu \mathrm{mol} \mathrm{CO} \mathrm{CO}_{2} \cdot \mathrm{kg}^{-1} \cdot \mathrm{h}^{-1}$ per week at $10^{\circ} \mathrm{C}$ for control, $\mathrm{MH}_{1}$ and $\mathrm{MH}_{2}$-treated onions respectively. The determination coefficients $\left(R^{2}\right)$ of the regression ranged from 0.90 and 0.97 . However at $4^{\circ} \mathrm{C}, \mathrm{RR}$ remained stable although the respiration rate of control bulbs increased slightly from 0.08 to 0.10 mmol. $\mathrm{kg}^{-1} \cdot \mathrm{h}^{-1}$ after 24 weeks of storage.
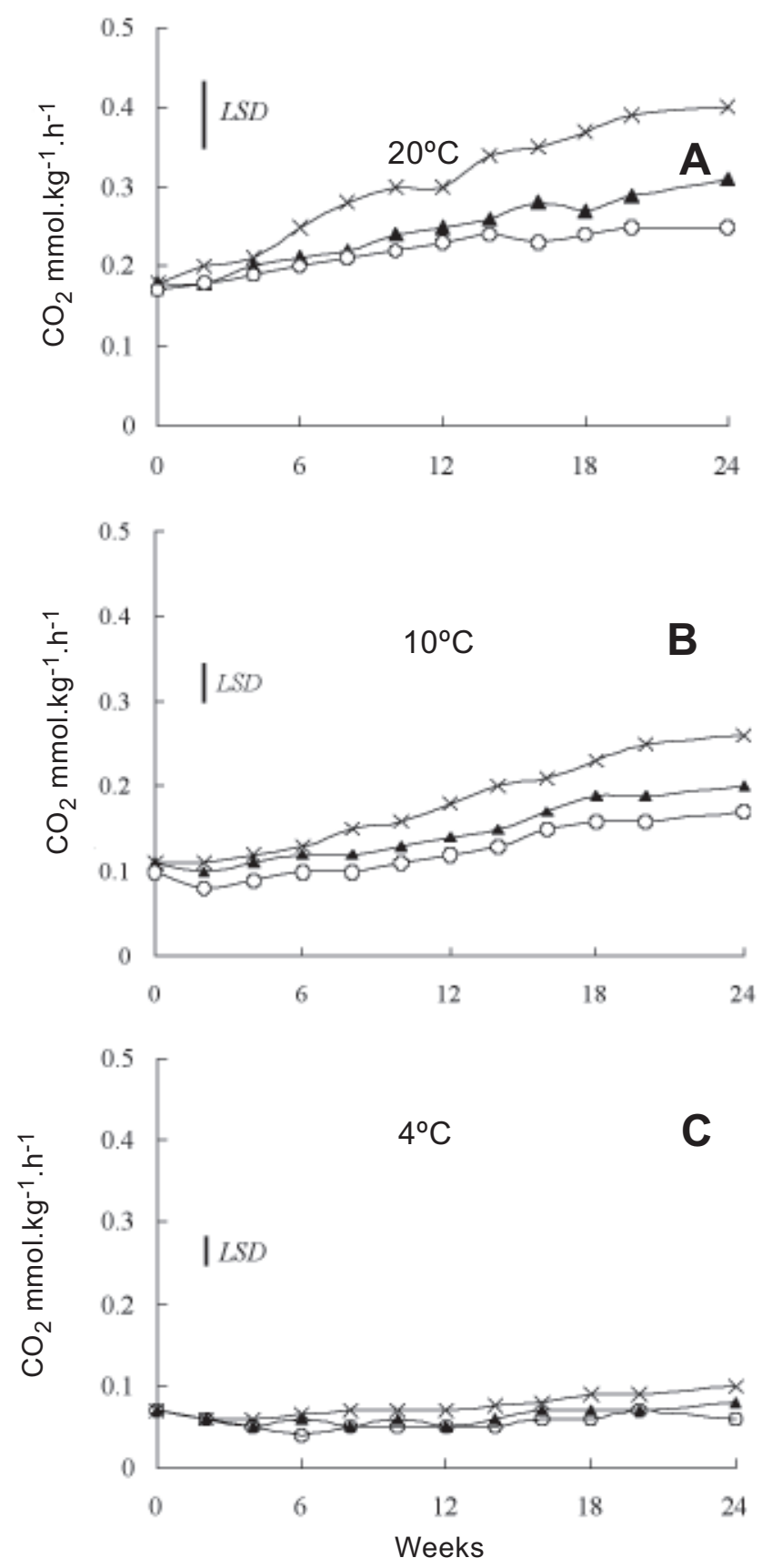

Figure 1. Effect of maleic hydrazide and temperature on respiration rate $\left(\mathrm{CO}_{2}\right.$ production) of onion bulbs during storage $\left(\times\right.$ control, $\left.\mathbf{\Delta} \mathrm{MH}_{1}, \bigcirc \mathrm{MH}_{2}\right)(L S D$ at $P<0.05)$. 
These results agree with other previous investigations. Salama and Hicks (1987) reported an increase in respiration rate of bulbs treated with maleic hydrazide but this increase was lower than observed in control bulbs. Similar results were reported by Kato (1970) and Ward and Tucker (1976), and the former noted that the increase in respiration rate of bulbs depended on the severity of the initial stress caused by $\mathrm{MH}$. Benkeblia et al (2002) also noted that RR of MH-treated onion bulbs increased after six months from 0.17 to 0.20 and 0.26 mmol. $\mathrm{kg}^{-1} \cdot \mathrm{h}^{-1}$ at 10 and $20^{\circ} \mathrm{C}$ respectively.

During storage at 10 and $20^{\circ} \mathrm{C}$, sprouting of onion bulbs was visible after 6 and 10 weeks, whereas at $4^{\circ} \mathrm{C}$, sprouting was visible only after 16 weeks. After 24 weeks, sprouting of the control bulbs was 50 and $75 \%$ at 10 and $20^{\circ} \mathrm{C}$ respectively (figures $2 \mathrm{~A}$ and $\mathrm{B}$ ). At the same temperatures, sprouting of treated bulbs was 22 and $38 \%$ for $\mathrm{MH}_{1}$, and
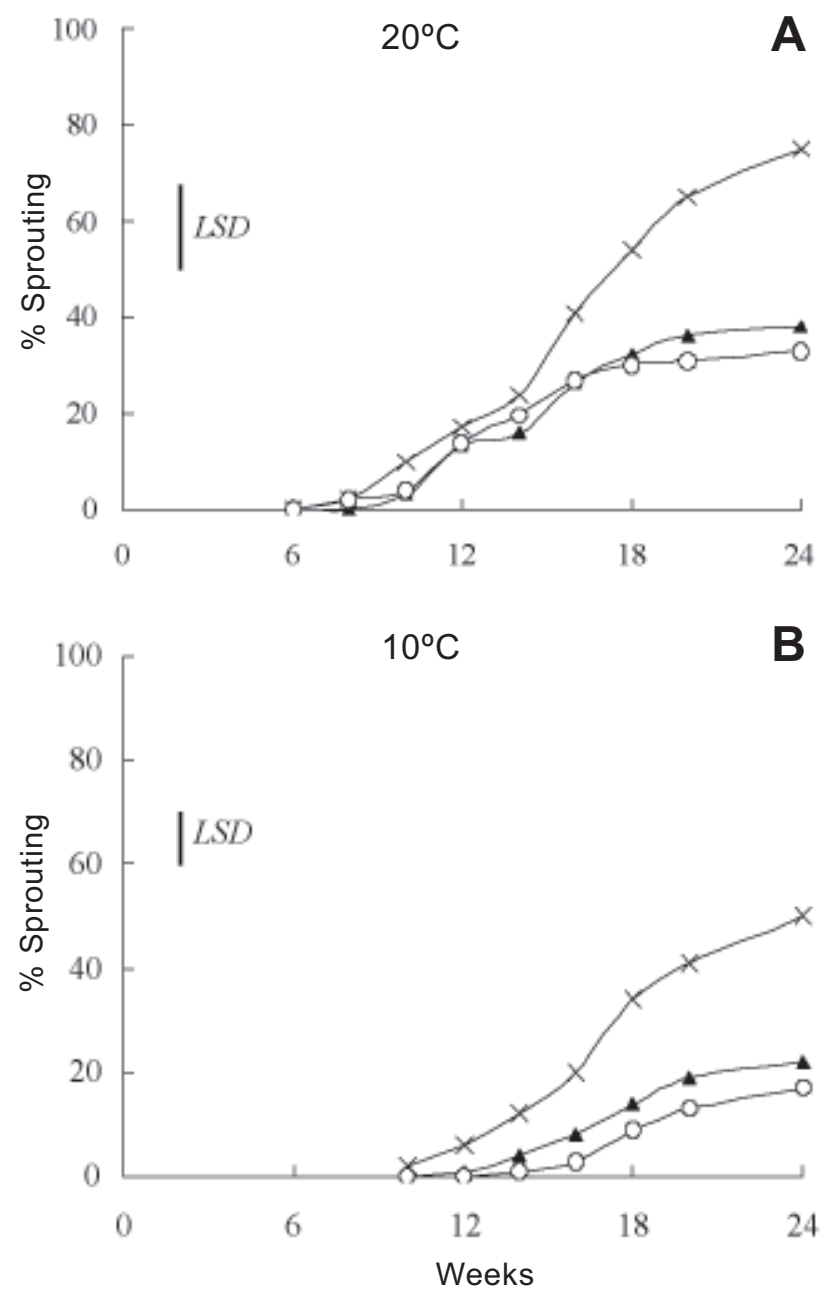

Figure 2. Effect of maleic hydrazide on sprouting of onion bulbs stored at 4,10 and $20^{\circ} \mathrm{C}\left(\times\right.$ control, $\left.\mathbf{\Delta} \mathrm{MH}_{1}, \bigcirc \mathrm{MH}_{2}\right)$ ( $L S D$ at $P<0.05$ ).
17 and $33 \%$ for $\mathrm{MH}_{2}$. This indicates that intermediary temperatures seemed more favorable for the sprouting of onion bulbs regardless of the chemical treatment applied. On the other hand after 24 weeks at $4^{\circ} \mathrm{C}$, the sprouting level of control and $\mathrm{MH}$-treated bulbs was very low, ranging from 5\% (treated bulbs) and 7\% (control) without any significant difference (data not shown).
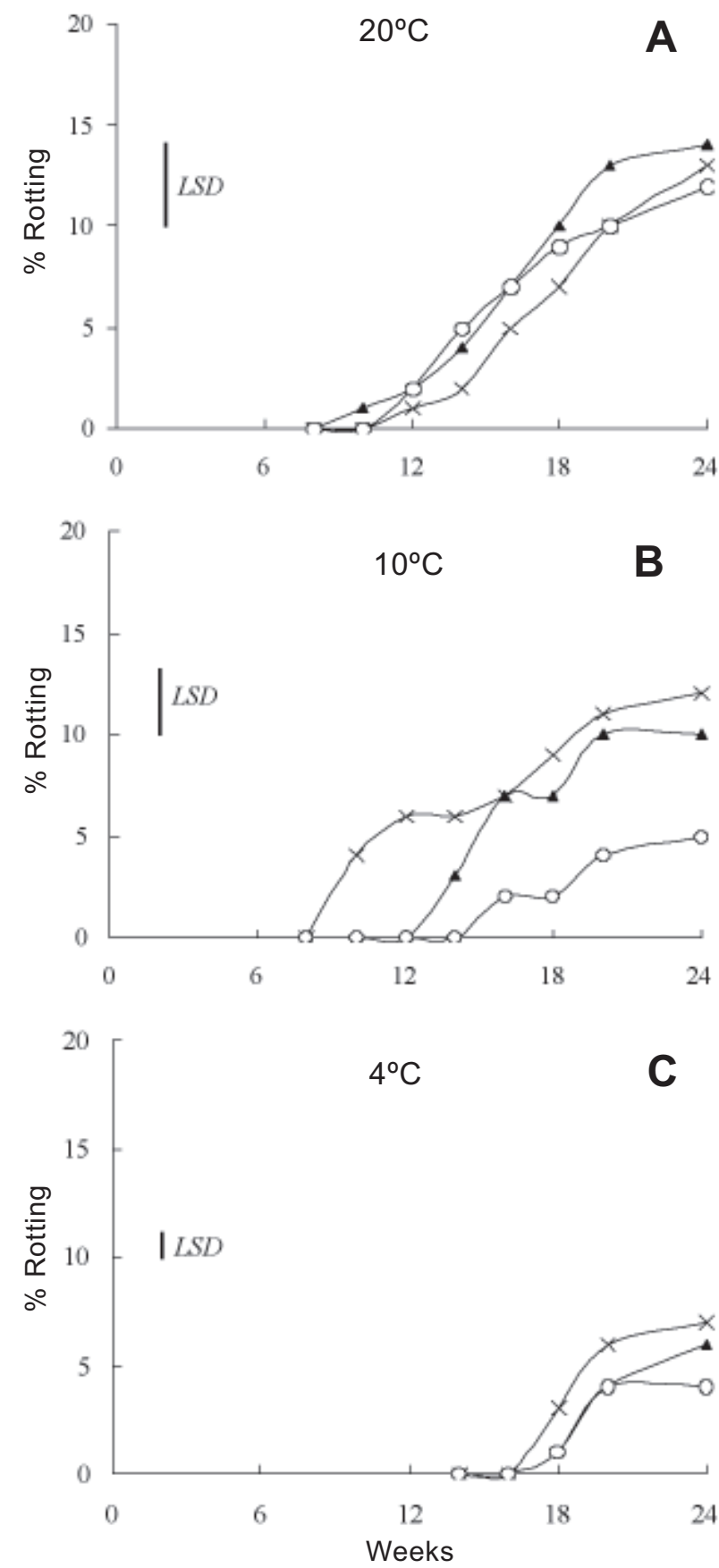

Figure 3. Effect of maleic hydrazide on rotting of onion bulbs stored at 4,10 and $20{ }^{\circ} \mathrm{C}\left(\times\right.$ control, $\left.\mathbf{M} \mathrm{MH}_{1}, \mathrm{OMH}_{2}\right)$ ( $L S D$ at $P<0.05$ ). 
Effects of MH on sprout inhibition of onion bulbs have been extensively investigated (Isenberg and Ferguson, 1981; Nawaz et al., 1988; Sinha et al., 1994). However, other factors can affect or induce the sprouting of the bulbs during storage, e.g. maturity of the bulbs at harvesting (Tucker and Morris, 1984), dry matter and carbohydrate content (Rutherford and Wittle, 1984) and cultivar (Miedema, 1994; Benkeblia, 1999). An effect of maleic hydrazide on rotting was less visible and the low attacks observed at 4 and $10^{\circ} \mathrm{C}$ could be attributed to the low temperature, which inhibit fungal and bacterial propagation (figures $3 \mathrm{~A}, \mathrm{~B}$ and C). Statistically no significant difference was observed between control and $\mathrm{MH}$-treated bulbs; except at 4 and $10^{\circ} \mathrm{C}$ where a significant difference was observed between control and $\mathrm{MH}_{2}$-treated bulbs.

Rotting of onion bulbs during storage is caused by numerous bacteria and fungi species (Snowdon, 1991), and post-harvest diseases may place a major restriction on the long-term storage of onions. Reported results on rotting of onions during storage vary considerably, however there is clear evidence that cultivation methods and pre-harvest factors contribute largely to the post-harvest diseases of bulbs during storage (Maude, 1983; Schwartz and Mohan, 1995)

Finally, it is concluded that maleic hydrazide shows a marked effect on physiological parameters of onion bulbs particularly after 2 months storage when variations of measured parameters are significant and more visible. The knowledge of these physiological parameters could permit the prediction of gas exchanges of stored onion bulbs particularly under modified or controlled atmosphere. However, further investigations are needed to determine the effect of maleic hydrazide on catabolic pathways involved in sprouting of onion bulbs especially on carbohydrates which are essential for storage of onions as well as all other crops.

\section{REFERENCES}

Abdallah AA, Mann LK (1963) Bulb development in the onion (Allium cepa L.) and the effect of storage temperature and bulb rest. Hilgardia 35:85-112.

Appleton MD, Haab W, Eisenstadt ML, Rodgers R, Thoman CJ (1981) Incorporation of maleic hydrazide into ribonucleic acid of Sccharomyces cerevisiae. J. Agric. Food Chem. 29:986-989.

Benkeblia N (2003) Postharvest technology of onions. In: Dris, R, Niskanen R, Mohan Jain S (eds), Crop management and postharvest handling of horticultural products, pp.107-137. Science Publishers, Enfield (NH), USA.

Benkeblia N, Varoquaux P, Shiomi N, Sakai H (2002) Storage technology of onion bulbs c.v. Rouge Amposta: effect of irradiation, maleic hydrazide and carbamate isopropyl, Nphenyl (CIP) on respiration rate and carbohydrates. J. Food Sci. Technol. 37:169-176.
Benkeblia N, Varoquaux P, Gouble B, Selselet-Attou G (2000) Respiratory parameters of onion bulbs. Effects of irradiation and temperature. J. Sci. Food Agric. 80:1772-1778.

Benkeblia N (1999) Effect of harvest time, cultivar and storage temperature on sprouting of onion bulbs (Allium cepa L.). Allium Imp. Newsletter 9:24-26.

Isenberg FMR, Ferguson WL (1981) Maleic hydrazide for use on storage onions. Search Agri. Cornell Univ. Ithaca 15:1-21.

Kato T (1970) Studies on the mechanism of retardation of sprouting and occurrence of functional disorders in onion bulbs applied with maleic hydrazide. J. Jap. Soc. Hort. Sci. 5:80-86.

Komossa D, Sandermann H (1995) Plant metabolic studies of the growth regulator maleic hydrazide. J. Agric. Food Chem. 43:2713-2715.

Kubo Y, Inaba A, Nakamura R (1990) Respiration and $\mathrm{C}_{2} \mathrm{H}_{4}$ production in various harvested crops held in $\mathrm{CO}_{2}-$ enriched. J. Amer. Soc. Hort. Sci. 115:975-978.

Labuza TP (1983) Active packaging technologies for improved shelf-life and quality. In: Yalpani M (ed), Science for the food industry of the $21^{\text {st }}$ century. Vol. 2. pp.265284. ATL Press, Mount Prospect (IL), USA.

Maude RB (1983) Onions. In: Dennis C (ed), Post-harvest pathology of fruits and vegetables, pp.73-100. Academic Press, London, UK.

Miedema P (1994) Bulb dormancy in onion. I: The effects of temperature and cultivar on sprouting and rooting. J. Hort. Sci. 69:29-39.

Nawaz A, Wahid M, Inayatullah H (1988) Effect of maleic hydrazide spray and irradiation on the storage of onions. The Nucleus 25:39-42.

Peppelenbos HW, Tijskens LMM, van't Leven J, Wilskinson EC (1996) Modelling oxidative and fermentation carbon dioxide production of fruits and vegetables. Postharvest Biol. Technol. 9:283-295.

Rutherford PP, Wittle R (1984) Methods predicting the long term storage of onions. J. Hort. Sci. 59:537-543.

Salama AM, Hicks JR (1987) Respiration and fresh weight of onion bulbs as affected by storage temperature, humidity and maleic hydrazide. Trop. Sci. 27:233-238.

Schwartz, HF, Mohan, SK (1995) Compendium of onion and garlic diseases. APS Press. St Paul, Minnesota.

Sinha P, Sharma RP, Roy MK (1994) Management of storage rot in onion through gamma irradiation and chemicals. J. Food Sci. Technol. 31:341-343.

Snowdon AL (1991) Post-harvest disease and disorders in fruits and vegetables. Vol. 2. Vegetables. Wolfe Scientific, London.

Tucker WG, Morris GEL (1984) A study of the effect of the environment during growth on sprouting of bulb onions in store. J. Ho rt. Sci. 59:217-227.

Van der Berg L, Lentz CP (1972) Respiratory heat production of vegetables during refrigerated storage. J. Amer. Soc. Hort. Sci. 97:431-432.

Ward CM, Tucker WG (1976) Respiration of maleic hydrazide treated and untreated onion bulbs during storage. Ann. Appl. Biol. 82:135-141.

Weichmann J (1987) Postharvest physiology of vegetables. Marcel Dekker, New York. 